\title{
Pemetaan Sosial dan Ekonomi Masyarakat Di Sekitar Kampus ITS Surabaya
}

\author{
Sutikno1, Imam Baihaqi2, Dyah Santhi Dewi3, Mochamad Yusuf4, Novianti Ika Sari5 \\ 1Statistika, Institut Teknologi Sepuluh Nopember \\ 2Manajemen Bisnis, Institut Teknologi Sepuluh Nopember \\ 3Teknik Industri, Institut Teknologi Sepuluh Nopember \\ 4Perencanaan dan Wilayah Kota, Institut Teknologi Sepuluh Nopember \\ 5Pusat Studi Potensi Daerah dan Pemberdayaan Masyarakat - LPPM, Institut Teknologi Sepuluh Nopember \\ (ITS) Surabaya Jl. Arif Rahman Hakim, Sukolilo, Indonesia \\ tikno@yahoo.com
}

\begin{abstract}
Abstrak
Keberadaan ITS memberikan dampak besar bagi masyarakat di sekitarnya terutama dalam usaha peningkatan sosial ekonomi. Guna memenuhi tanggung jawabnya, maka ITS bermaksud melakukan campus social responsibility (CSR). Tujuan penelitian adalah pemetaan sosial sebagai data dan informasi awal untuk membuat usulan program bagi warga sekitar. Metodologi yang dilakukan dalam penelitian ini adalah pengumpulan data/ survei kepada pihak RT, analisis data menggunakan analisis deskriptif, tabulasi silang, dan SWOT. Analisis lanjutan setelah dilakukan pemetaan sosial, klasifikasi karakteristik wilayah masing-masing kelurahan. Karakteristik kelurahan Keputih dan Gebang Putih memiliki kondisi yang hampir sama, yaitu kondisi sosial ekonomi tergolong menengah dan memiliki potensi pengembangan yang tinggi. Sedangkan, kondisi sosial ekonomi di Kejawan Putih Tambak berbeda dengan dua kelurahan yang lain, sosial ekonomi masih rendah serta potensi pengembangan SDA/ SDM yang belum optimal. Hasil analisis SWOT dirumuskan strategi sbb: (1) Peningkatan Ekonomi Mikro dan Kewirausahaan (2) Peningkatan Kapabiltas Masyarakat Terhadap Teknologi, (3) Menciptakan lingkungan yang aman dan resiliens terhadap kerawanan bencana, (4) Peningkatan norma dan etika internal ITS, (5) Meningkatkan kerjasama antar warga dan internal ITS, dan (6) Peningkatan Kualitas Hidup Masyarakat Sekitar.
\end{abstract}

Kata kunci: CSR ITS, Analisis Deskriptif, Program Unggulan

\section{PENDAHULUAN}

Institut Teknologi Sepuluh Nopember (ITS) Surabaya merupakan salah satu universitas ternama di Surabaya. Keberadaan ITS memberikan pengharapan besar bagi masyarakat di sekitarnya terutama dalam usaha peningkatan sosial ekonomi. Guna merealisasikan harapan warga di sekitar kampus, maka ITS bermaksud mengadopsi konsep tanggung jawab sosial perusahaan. Konsep perusahaan yang dikenal dengan corporate social responsibility (CSR) akan disesuaikan oleh ITS menjadi campus social responsibility (CSR).

Sistem manajemen yang belum sinergis antara masyarakat dan kampus menimbulkan berbagai persoalan dalam kelancaran pelaksanaan program CD/CSR. Jika dirancang dengan baik maka program community development ini akan dapat meminimalkan kesenjangan tersebut. Selain itu kegiatan community development memang diharapkan dapat dirasakan oleh masyarakat di sekitar lokasi kegiatan karena dapat memberikan solusi terhadap persoalan yang ada, meningkatkan kesejahteraan sosial, meminimalkan dampak negatif yang diterima masyarakat dan lingkungan, dan menjaga keharmonisan hubungan antara masyarakat, pihak industri serta pemerintah setempat. Untuk itu, sebagai salah satu solusinya adalah melakukan pemetaan sosial sebagai data dan informasi awal, yang dilanjutkan dengan analisis hasil pemetaan sosial sehingga dapat diperoleh usulan program yang sesuai dengan kebutuhan warga disekitar ITS. Wilayah-wilayah yang langsung berbatasan dengan ITS meliputi Kelurahan Keputih, Kelurahan Kejawan Putih dan Kejawan Putih Tambak.

Berdasarkan informasi di atas, maka beberapa tujuan dari penelitian ini adalah (1) Mengidentifikasi kondisi sosial ekonomi masyarakat di sekitar lokasi kegiatan kampus ITS berdasarkan struktur komunitas yang ditinjau dari aspek sosial, ekonomi, dan politik; (2) Mengidentifikasi persoalan sosial yang ada serta potensi/ sumber daya yang dimiliki oleh daerah di sekitar lokasi kampus; (3) Mengidentifikasi kebutuhan dan harapan masyarakat yang dapat berdampak luas terhadap pembangunan berkelanjutan dalam 5 tahun ke depan dari segi sosial dan ekonomi. 


\section{TINJAUAN PUSTAKA}

\subsection{Corporate Sosial Responsibility (CSR)}

Konsep tanggung jawab sosial perusahaan (corporate social responsibility: CSR) sangat berkaitan erat dengan konsep sustainability development (pembangunan yang berkelanjutan). Adanya konsep CSR mewajibkan perusahaan untuk memiliki tanggung jawab terhadap pihak-pihak lain, seperti: karyawan, supplier, konsumen, komunitas setempat, masyarakat secara luas, pemerintah, dan kelompok lainnya. Pelaksanaan CSR di Indonesia lebih sering dipahami sebagai upaya pengembangan masyarakat (community development) oleh perusahaan, yang diperuntukkan untuk masyarakat di sekitar lokasi perusahaan. Program CSR merupakan suatu bagian dari upaya pengembangan institusi/perusahaan dalam bidang pengurangan kemiskinan, pelestarian lingkungan, dan pembangunan ekonomi berkelanjutan [1].

\subsection{Pemetaan Sosial Ekonomi}

Pemetaan Sosial Ekonomi (baseline survey) merupakan salah satu metode sebagai langkah awal dalam manajemen CSR. Metode ini berguna sebagai tahapan awal dalam manajemen CSR dan berfungsi untuk memberikan analisa kuantitatif dan kualitatif bagi pelaksanaan program CSR selanjutnya [1]

Pemetaan jaringan sosial dapat memberikan gambaran bagi para pemangku kepentingan, bahwa program CSR dibuat secara bersama-sama sesuai dengan kepentingan masyarakat dan visi misi institusi. dalam penyusunan program CSR Perlu diketahui dalam bentuk skema,bagaimana hubungan dari institusi maupun masyarakat di sekitarnya, termasuk dalam penyusunan program Community Development pengembangan masyarakat. Dalam perumusan program Community Development (pengembangan masyarakat) terdapat beberapa hal yang harus diperhatikan [2].

a. Proses perencanaan melibatkan anggota masyarakat

b. Analisis isu strategis pengembangan masyarakat (CD)

c. Program bersifat jangka panjang dan dirinci dengan program tahunan

d. Program menjawab kebutuhan kelompok rentan

e. Indikator untuk mengukur kinerja capaian program yang terukur

\subsection{Statistika Deskriptif}

Singgih Santosa (2002) menyatakan, pada prinsipnya statistik diartikan sebagai kegiatan untuk mengumpulkan data, meringkas/menyajikan data, menganalisa data dengan metode tertentu, dan menginterpretasikan hasil analisis tersebut. Adapun beberapa karakteristik pokok statistik antara lain [3]:

a. Statistik bekerja dengan angka

b. Statistik bersifat obyektif

c. Statistik bersifat universal

Sementara, berdasarkan jenisnya statistik dibedakan menjadi dua yaitu statistik deskriptif dan statistik inferensia. Adapun jenis statistik yang digunakan dalam penelitian ini adalah statistik deskriptif yaitu metode statistika yang berkaitan dengan pengumpulan dan penyajian data sehingga memberikan informasi yang berguna [4]. Statistik deskriptif hanya memberikan informasi mengenai data yang ada tanpa menarik kesimpulan dan mengambil keputusan. Statistik deskriptif dapat disajikan dengan tabel dan diagram/grafik.

\subsection{Analisis Konten}

Metode Content Analysis merupakan analisis ilmiah tentang isi pesan suatu komunikasi [5]. Dalam hal ini, content analysis mencakup: klasifikasi tanda-tanda yang dipakai dalam komunikasi, menggunakan kriteria sebagai dasar klasifikasi, dan menggunakan teknik analisis tertentu sebagai pembuat prediksi. Deskripsi yang diberikan para ahli sejak diungkapkan Janis, Berelson sampai Lindzey dan Aronson tentang Content Analysis menampilkan tiga syarat, yaitu: objektivitas, dengan menggunakan prosedur serta aturan ilmiah; generalitas, dari setiap penemuan studi mempunyai relevansi teoritis tertentu; dan sistematis, seluruh proses penelitian sistematis dalam kategorisasi data.

\subsection{Penelitian Sebelumnya}

Alshuwaikhat dan Abubakar (2008) melakukan penelitian mengenai kebutuhan untuk mencapai universitas yang berkelanjutan. Manajemen universitas yang berkelanjutan didefinisikan sebagai perguruan tinggi yang secara keseluruhan maupun sebagian membahas, terlibat, dan mempromosikan di tingkat nasional maupun internasional untuk meminimalisasi dampak negatif (lingkungan, ekonomi, sosial dan kesehatan) [6]. Perguruan tinggi dapat pula membantu keberlanjutan wilayah sekitarnya dengan kegiatan belajar mengajar, penelitian,dan kerjasama dengan stakeholder. Definisi lain dari sustainable campus community adalah kegiatam baik secara lokal maupun global memiliki kewajiban untuk menjaga menjaga kesehatan dan kesejahteraan masnusia dan ekosistem di sekitarnya. Alshuwaikhat dan Abubakar (2008) menjabarkan bahwa terdapat 3 (tiga) pendekatan yang ditawarkan untuk mencapai kampus yang berkelanjutan yaitu (1) University environmental management system (EMS), (2) partisipasi masyarakat \& tanggung jawab sosial, (3) kegiatan belajar mengajar yang bekerlanjutan dan riset. Pendekatan yang nomor dua tersebut kemudian kita sebut dengan Campus Sosial Responsibility. 


\section{METODE PENELITIAN}

\subsection{Persiapan}

Tahap persiapan terdiri dari diskusi/ brainstorming, penyusunan kerangka sampling \& penyiapan instrument, survei lapangan,dan open rekruitmen surveyor serta brifing surveyor. Diskusi dan brainstorming bersama tenaga ahli dilakukan untuk menyamakan persepsi antar ketua dan anggota.

Metode sampling yang digunakan adalah purposive sampling yang biasa disebut judgement sampling. Satuan sampling dipilih berdasarkan pertimbangan tertentu dengan tujuan untuk memperoleh satuan sampling yang memiliki karakteristik yang dikehendaki[4]. Sampel dipilih berdasarkan penilaian peneliti bahwa dia adalah pihak yang paling baik untuk dijadikan sampel penelitiannya. Distribusi sampel untuk kegiatan ini disesuaikan dengan jumlah Rukun Tetangga (RT) di wilayah cakupan studi yang ada di 3 kelurahan yang tersebar di 2 kecamatan. Unit sampel untuk kegiatan ini adalah responden tertentu yang mewakili setiap RT/ RW. Secara umum, kriteria responden dalam studi ini adalah: aparat pemerintahan (kelurahan), tokoh masyarakat (Ketua RW, Ketua RT, Tokoh agama, Tokoh wanita, dan Tokoh masyarakat lainnya) Jumlah sampel yang didapatkan untuk kegiatan ini sejumlah 88 responden. Jumlah sampel tersebut tersebar di tiga kelurahan seperti pada Tabel 1 .

Tabel 1. Pengambilan Sampel Penelitian Kebijakan ITS

\begin{tabular}{|c|c|c|c|c|c|}
\hline \multirow{2}{*}{ No. } & \multirow{2}{*}{ Kecamatan } & \multirow{2}{*}{ Kelurahan } & \multicolumn{3}{|c|}{ Jumlah Wilayah Jumlah Sampel } \\
\hline & & & RW & RT & \\
\hline \multirow{2}{*}{1} & & Keputih & 5 & 8 & 35 \\
\hline & & $\begin{array}{c}\text { Gebang Putih } \\
\text { Kejawan Putih }\end{array}$ & 4 & 5 & 24 \\
\hline 2 & Mulyorejo & Tambak & 3 & 6 & 29 \\
\hline
\end{tabular}

\subsection{Pengumpulan Data}

Sumber data yang digunakan dalam studi ini terdiri atas 2 jenis, yaitu: data sekunder dan data primer. Data sekunder adalah data yang berasal dari dokumen eksisting yang dikeluarkan oleh kampus ITS maupun dokumen yang dipublikasikan oleh instansi terkait (BPS Kota Surabaya, Pemerintah Kecamatan dan Pemerintah Kelurahan). Kebutuhan data sekunder yang relevan dalam studi ini diantaranya:

- Data-data demografi, potensi kelurahan, sarana dan prasarana yang ada yang terdapat dalam Monografi Kelurahan atau Kecamatan dalam Angka.

- Peta - peta wilayah administrasi, lokasi kampus dan sekitarnya.

Sedangkan data primer adalah data yang diperoleh melalui survei dan pengamatan langsung, baik terhadap kampus maupun terhadap masyarakat. Adapun metodologi yang digunakan dalam proses pengumpulan data adalah survei penyebaran kuesioner. Survei adalah pengumpulan data dimana data yang diselidiki adalah sampel dari populasi. Instrumen yang digunakan adalah kuesioner, dimana tersusun secara sistematis dan standar sehingga pertanyaan yang sama dapat diajukan terhadap setiap responden. Penyebaran kuesioner dilakukan kepada masyarakat di sekitar kawasan ITS dan jurusan-jurusan di lingkungan ITS. Wawancara dipandu dengan kuisioner serta check list yang meliputi semua aspek sosial (yang telah diuraikan dalam ruang lingkup). Kegiatan survei dilakukan selama 1 (satu) bulan. Hal ini dikarenakan responden yang ditemui jarang berada di rumah.

Dalam rangka penyusunan roadmap CSR ITS, dilakukan pendalaman diskusi dengan para pimpinan ITS. Hal ini untuk menstrategiskan program-program usulan mana yang sesuai dengan Visi-Misi ITS. Penjaringan aspirasi dilakukan dengan metode diskusi mendalam, dimana metode untuk mengumpukan data secara kualitatif, khususnya dalam proses pengambilan keputusan.

\subsection{Metode Analisis Data}

Analisis yang digunakan adalah analisis deskriptif (baik secara kuantitatif maupun kualitatif), analisis konten, dan teknik skoring. Hasil pemetaan sosial akan menjelaskan kondisi eksisting dari wilayah studi baik yang diperoleh dari data sekunder maupun data primer meliputi: struktur demografi, kondisi sosial ekonomi masyarakat (tingkat kesejahteraan masyarakat), dan potensi konflik. Hasil dari pemetaan kondisi eksisting kemudian akan dilakukan analisis klasifikasi karakteristik wilayah dengan memberikan skoring. Teknik skoring adalah metode pemberian skor pada masing-masing variabel sesuai parameter yang digunakan. Parameter yang digunakan dalam penelitian ini tidak bersifat universal artinya parameter ini tidak dapat digunakan untuk penelitian lain. Masing-masing kegiatan analisis memiliki parameter yang berbeda tergantung pada konteks analisa. Namun semua parameter dalam analisa tersebut sama-sama diperoleh dari hasil temuan-temuan analisa konten.

\section{HASIL DAN PEMBAHASAN}

\subsection{Analisa Karakteristik Wilayah Studi}


Pemetaan sosial ekonomi dan potensi pengembangan wilayah di tiap kelurahan memiliki karakteristik berbeda seperti dijelaskan. Pada Tabel 2. kondisi demografi dijabarkan ke bidang Ekonomi, Sosial, Budaya, Persepsi pengaruh ITS, serta kondisi demografi penduduk.

Tabel 2. Analisis Karakteristik Wilayah

\begin{tabular}{|c|c|c|c|}
\hline BIDANG & KEPUTIH & GEBANG PUTIH & $\begin{array}{l}\text { KEJAWAN PUTIH } \\
\text { TAMBAK }\end{array}$ \\
\hline Ekonomi & $\begin{array}{l}\text { Pekerjaan mayoritas wiraswasta } \\
\text { Usaha yang dilakukan skala rumah } \\
\text { tangga (u/ memenuhi kebutuhan } \\
\text { mahasiswa) } \\
\text { - } \\
\text { Ada potensi untuk pengembangan } \\
\text { pengolahan Ikan } \\
\text { - } \\
\text { Ada petambak (150 warga) } \\
\text { Ada nelayan (hanya } 1 \mathrm{KK}) \\
\text { Tingkat kesejahteraan KS III }(43 \%)\end{array}$ & $\begin{array}{l}\text { Pekerjaan mayoritas } \\
\text { Wiraswasta } \\
\text { Usaha yang dilakukan skala } \\
\text { rumah tangga } \\
\text { Terdapat petani tambak } \\
\text { Tingkat kesejahteraan KS III } \\
(39 \%)\end{array}$ & $\begin{array}{l}\text { Pekerjaan mayoritas pegawai } \\
\text { swasta } \\
\text { Usaha yang dilakukan skala } \\
\text { rumah tangga } \\
\text { Ada Nelayan ( } 42 \text { warga) } \\
\text { Ada } 16 \text { petambak } \\
\text { Tingkat Kesejahteraan KS II } \\
(37 \%)\end{array}$ \\
\hline $\begin{array}{l}\text { Sosial } \\
\text { Budaya }\end{array}$ & $\begin{array}{l}\text { KK tidak bekerja } 6 \% \\
\text { Modal sosial warga:mudah } \\
\text { beradaptasi, plural, potensi konflik } \\
\text { dengan mahasiswa sedang, potensi } \\
\text { antar warga tinggi } \\
\text { Pendidikan paling banyak lulusan } \\
\text { Universitas }\end{array}$ & $\begin{array}{l}\text { KK tidak bekerja } 11 \% \\
\text { Modal sosial : mudah } \\
\text { beradaptasi, potensi konflik } \\
\text { dengan mahasiswa tinggi, } \\
\text { potensi antar warga rendah } \\
\text { Pendidikan paling banyak } \\
\text { lulusan SMA }\end{array}$ & $\begin{array}{l}\text { KK tidak bekerja } 36 \% \\
\text { Modal sosial : akrab, potensi } \\
\text { konflik dengan mahasiswa } \\
\text { rendah, potensi antar warga } \\
\text { Rendah } \\
\text { Pendidikan paling banyak } \\
\text { lulusan SMA }\end{array}$ \\
\hline $\begin{array}{l}\text { Persepsi } \\
\text { pengaruh } \\
\text { ITS }\end{array}$ & $\begin{array}{l}\text { ITS berpengaruh positif \& } \\
\text { signifikan pada kegiatan warga }\end{array}$ & $\begin{array}{l}\text { ITS berpengaruh positif pada } \\
\text { kegiatan warga }\end{array}$ & $\begin{array}{l}\text { ITS berpengaruh positif } \\
\text { namun tidak signifikan }\end{array}$ \\
\hline Demografi & Stasioner & Ekspansif & Konstruktif \\
\hline
\end{tabular}

Berdasarkan karakteristik wilayah di atas dapat dikelompokkan menjadi dua indikator yaitu indikator sosial ekonomi dan indikator potensi pengembangan. Indikator ini dibuat untuk memudahkan penyusunan strategi dan roadmap CSR ITS. Selanjutnya dibuat variabel tiap indikator dengan tingkatan skoring tertentu secara lengkap disajikan pada Tabel 3.

Tabel 3. Variabel Indikator Sosial Ekonomi dan Potensi Pengembangan

\begin{tabular}{|c|c|c|}
\hline Skoring & Indikator Sosial Ekonomi & Indikator Potensi Pengembangan \\
\hline 1 & $\begin{array}{l}\text { - Tingkat pengangguran tinggi }>30 \% \\
\text { - Tingkat kesejahteraan }<\text { KS III } \\
\text { - Tingkat kondusifitas (konflik, suasana } \\
\text { pergaulan) tinggi }>60 \% \\
\text { - Fleksibilitas penyampaian informasi rendah } 0 \text { - } \\
30 \%\end{array}$ & $\begin{array}{l}\text { - Keberadaan ITS berpengaruh negatif kepada warga sekitar } \\
\text { - Potensi pengembangan penduduk menjadi desa berdaya } \\
\text { rendah (piramida konstruktif, pendidikan rendah, tingkat } \\
\text { kesejahteraan pra-sejahtera) } \\
\text { - Potensi pengembangan skala lokal- regional- nasional rendah } \\
\text { (tidak ada potensi SDA) }\end{array}$ \\
\hline 2 & $\begin{array}{l}\text { - Tingkat pengangguran sedang } 11-30 \% \\
\text { - Tingkat kesejahteraan KS III } \\
\text { - Tingkat kondusifitas (konflik, suasana } \\
\text { pergaulan) sedang } 31-60 \% \\
\text { - Fleksibilitas penyampaian informasi sedang } 31 \text { - } \\
60 \%\end{array}$ & $\begin{array}{l}\text { - Keberadaan ITS tidak berpengaruh } \\
\text { - Potensi pengembangan penduduk menjadi desa berdaya } \\
\text { sedang (piramida ekspansiv, pendidikan sedang, tingkat } \\
\text { kesejahteraan menengah) } \\
\text { - Potensi pengembangan skala lokal- regional- nasional sedang } \\
\text { (ada potensi SDA minim SDM) }\end{array}$ \\
\hline 3 & $\begin{array}{l}\text { - Tingkat pengangguran rendah } 0-10 \% \\
\text { - Tingkat kesejahteraan KS III+ } \\
\text { - Tingkat kondusifitas (konflik, suasana } \\
\text { pergaulan) rendah } 0-30 \% \\
\text { - Fleksibilitas penyampaian informasi tinggi > } \\
61 \%\end{array}$ & $\begin{array}{l}\text { - Keberadaan ITS berpengaruh positif } \\
\text { - Potensi pengembangan penduduk menjadi desa berdaya tinggi } \\
\text { (stasioner, pendidikan tinggi, tingkat kesejahteraan tinggi) } \\
\text { - Potensi pengembangan skala lokal- regional- nasional tinggi } \\
\text { (ada potensi SDA dan SDM berkualitas) }\end{array}$ \\
\hline
\end{tabular}




\section{SOSIAL EKONOMI}

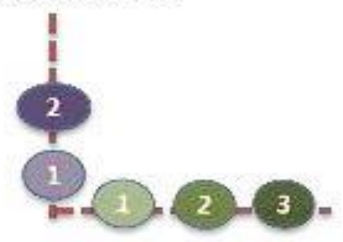

POTENSI PENGEMBANGAN

Gambar 1. Klasifikasi Karakteristik Kelurahan Keputih

Di Kelurahan Keputih seperti pada Gambar 1 kondisi ekonomi tergolong menengah karena sebagian besar menjadi wiraswasta. Kegiatan yang dilakukan adalah berjualan makanan, jasa laundry, jasa kos-kosan ataupun toko kelontong. Dan jenis usaha yang dilakukan masih skala rumah tangga, serta kebanyakan usaha muncul karena memenuhi kebutuhan mahasiswa dan warga pendatang. Keputih juga memiliki potensi untuk kegiatan ekonomi berupa petambak dan nelayan. Ikan yang dihasilkan perikanan darat berupa: udang dan bandeng. Budidaya tambak yang dilakukan di Keputih masih secara tradisional akibatnya jumlah ikan yang dipanen sedikit dan kecil-kecil. Selain itu petambak juga kesulitan dalam memasarkan olahan hasil tambaknya, serta ada ancaman untuk keberlangsungan tambak karena lahan yang digunakan untuk budidaya ikan semakin sempit banyak digunakan untuk lahan pemukiman. Hasil tangkapan ikan tidak banyak, namun disisi lain hal ini membuat kawasan mangrove di sekitarnya lebih lestari daripada wilayah tangkap lainnya di Surabaya. Meskipun demikian sebagian besar KK di Keputih sudah kategori keluarga KS III. Dari kondisi sosialnya, kelurahan Keputih memiliki modal sosial warga yang mudah beradaptasi, akrab dan plural karena banyak warga pendatang. Meskipun tergolong akrab, namun tetap ada potensi konflik antara warga serta antar warga dan mahasiswa atau warga pendatang lainnya. Adapun potensi pengembangan untuk daerah Keputih sangat bagus. Warga menganggap kalau ITS memberikan pengaruh positif dan cukup signifikan terutama pada kegiatan ekonomi warganya. Tingkat pendidikan tergolong tinggi karena sebagian besar KK lulusan universitas. Berdasarkan jenis usia penduduk, penduduk Keputih adalah penduduk stasioner, yaitu dimana tingkat kelahiran dan kematian seimbang. Biasanya penduduk stasioner terdapat di beberapa negara maju.

\section{Kelurahan Gebang Putih}

Secara umum kondisi ekonomi Gebang Putih kategori sedang seperti pada Gambar 2. Sebagian besar KK adalah kategori KS III, ini sesuai dengan tingkat pengangguran di Gebang hanya terdapat 11 persen KK. Kegiatan ekonomi wiraswasta masih bersifat skala rumah tangga dan usaha muncul karena memenuhi kebutuhan mahasiswa atau warga pendatang. Selain itu terdapat potensi kegiatan ekonomi berupa petambak, di Gebang terdapat pemukiman petambak tersebar di 4 RW. Kondisi ekonomi petambak Kejawan Putih Tambak masih menengah ke bawah karena cara budidaya yang dilakukan tradisional, sehingga hasil tangkapan tidak banyak.

Modal sosial warga Gebang Putih diantaranya mudah beradaptasi, akrab dan plural karena banyak warga pendatang. Kehidupan sosial di Gebang secara umum tergolong tenang dan nyaman. Meskipun demikian, potensi konflik antar warga serta antara warga dengan mahasiswa atau warga pendatang lainnya tetap ada. Hal yang sama dengan Keputih, potensi pengembangan SDM/SDA yang dimiliki Gebang Putih cukup banyak. Meskipun tingkat pendidikan sebagian besar KK hanya lulusan SMA, namun piramida penduduknya tergolong penduduk muda (ekspansive). Sebagian besar penduduknya pada usia muda. Dimana angka kelahiran lebih tinggi daripada angka kematian serta pertumbuhan penduduk terus meningkat.

\section{Kelurahan Kejawan Putih Tambak}

\section{SOSIAL EKONOMI}

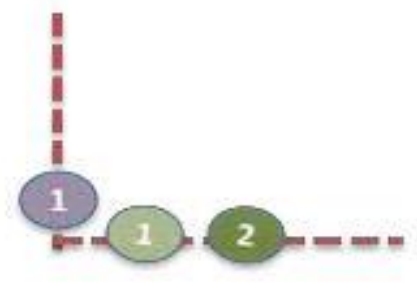

Gambar 3. Klasifikasi Karakteristik Kelurahan Kejawan Putih Tambak

\section{SOSIAL EKONOMI}

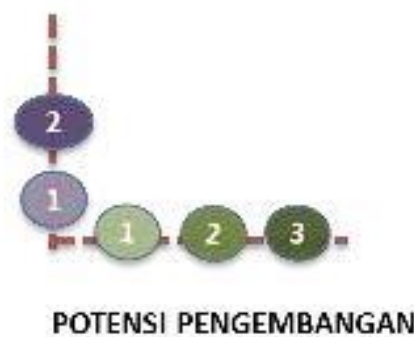

Gambar 2. Klasifikasi Karakteristik Kelurahan Gebang Putih banyak warga pendatang kebanyakan dari Madura.

Potensi pengembangan SDM/SDA yang dimiliki Gebang Putih tidak sebanyak di Keputih dan Gebang Putih. Tingkat pendidikan sebagian besar KK hanya lulusan SMA dan piramida penduduknya tergolong penduduk tua (konstructive). Sebagian besar penduduknya pada usia dewasa atau tua. Angka kematian lebih tinggi daripada angka kelahiran, pertumbuhan penduduk terus menurun. Potensi yang bisa dikembangkan adalah dari ikan tambaknya, bisa dikembangkan budidayanya serta hasil pengolahan ikannya. pada Gambar 3. Dimana sebagian besar KK merupakan kategori KS II. Tingkat pengangguran juga cukup tinggi mencapai 36 persen.

Di samping itu, terdapat potensi SDA yang berkembang di Kelurahan Kejawan Putih Tambak, yaitu budidaya ikan tambak dan ikan laut. Terdapat 42 nelayan dan 25 petani tambak. Tidak setiap KK juga memiliki 1 perahu, 1 perahu dimiliki oleh 5 KK. Nelayan di Kejawan Putih Tambak lebih memilih menggunakan cara yang tradisional (menjaga kearifan lokal) dalam melakukan kegiatan perikanannya. Dampaknya, kondisi ekonomi nelayan di Kejawan Putih Tambak termasuk menengah kebawah, salah satunya dikarenakan pilihan mereka untuk tetap menggunakan cara yang tradisional, sehingga hasil tangkapnya tidak terlalu banyak. Dari segi sosialnya, warga Kejawan Putih Tambak memiliki modal sosial warga akrab dan plural karena 


\subsection{Analisa SWOT}

Terhadap Karakteristik Daerah Sekitar Setelah mengklasifikasikan karakteristik wilayah diperlukan strategi untuk mengetahui langkah-langkah yang dapat diambil dalam rangka penyusunan program CSR ITS. Teknik analisa yang biasa digunakan untuk merumuskan strategi adalah analisa SWOT. Analisa SWOT merupakan teknik analisa yang mengharuskan kita untuk menemukenali kekuatan (strengths) dan kelemahan (weaknesses) yang berasal dari dalam (internal), serta peluang (opportunities) dan ancaman (threats) yang disebabkan oleh pihak luar (eksternal). Berdasarkan hasil SWOT di masingmasing kelurahan didapatkan strategi pengembangan di semua aspek yang selengkapnya di tunjukkan pada Tabel 4.

Tabel 4. Analisis Strategi

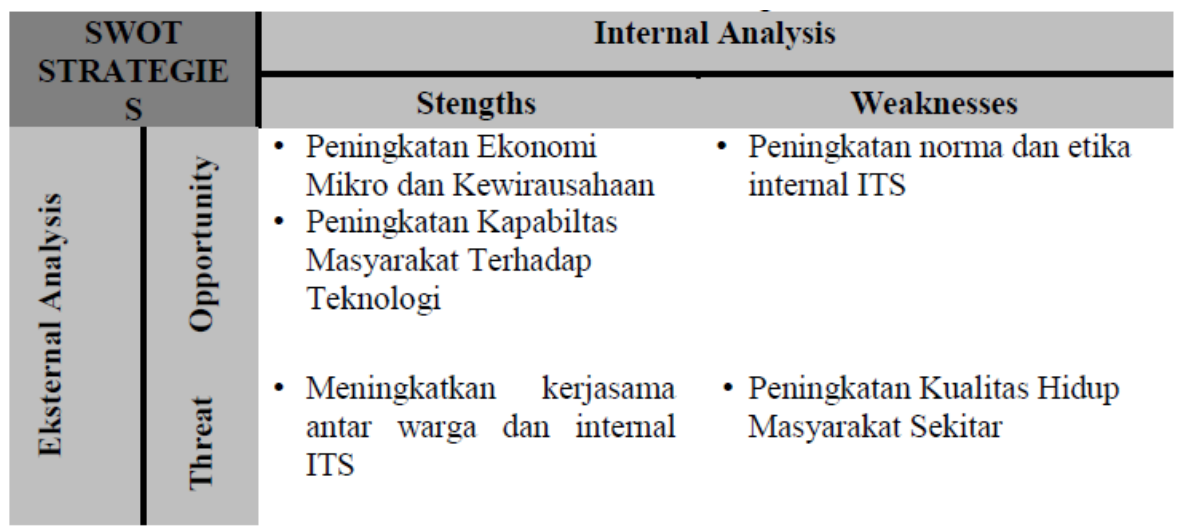

Analisis strategi di atas kemudian dapat dijadikan landasan dalam penyusunan program-program CSR ITS serta membantu dalam menstrategiskan roadmap CSR ITS dalam 5 tahunan ke depan, dimana beberapa usulan program diantaranya: Penataan PKL; Pelatihan untuk KSM/ UKM yang sudah ada (Setiap pelatihan di linkan ke Bank atau CSR di Perusahaan rekanan ITS); Menciptakan Kampung Tekno; Perbaikan Mutu Sekolah dan Kualitas Murid; Pembinaan Kepemudaan Karangtaruna dengan Melibatkan Mahasiswa.

\section{KESIMPULAN}

Berdasarkan tujuan penelitian, maka kesimpulan dalam penelitian ini adalah sebagai berikut:

1 Setiap kelurahan memiliki karakteristik yang unik, seperti di Kelurahan Kejawan Putih Tambak dan Keputih memiliki potensi kegiatan ekonomi oleh petambak dan nelayan. Karakteristik wilayah Gebang Putih hanya memiliki potensi kegiatan ekonomi dengan budidaya tambak.

2 Kondisi demografi penduduk di tiap kelurahan, kelurahan Keputih sebagian besar dihuni penduduk yang konstruktif, kelurahan Gebang Putih termasuk kategori penduduk expansive, dan kelurahan Kejawan Putih Tambak termasuk kategori penduduk stationare.

3 Potensi pengembangan di Keputih dan Gebang Putih kategori tinggi. Berbeda dengan di Kejawan Putih Tambak masih rendah karena kualitas SDM/ penduduknya masih rendah begitu pun dengan potensi SDA yang belum dikembangkan secara optimal.

4 Selanjutnya hasil dari analisa karakteristik wilayah digunakan untuk bahan analisis SWOT. Hasil analisis SWOT kemudian akan dipakai untuk membuat analisis strategi yang nantinya dijadikan landasan dalam penyusunan programprogram CSR ITS serta membantu dalam menstrategiskan roadmap CSR ITS dalam 5 tahunan ke depan.

5 Hasil analisis strategi meliputi:
a. Peningkatan Ekonomi Mikro dan Kewirausahaan
b. Peningkatan Kapabiltas Masyarakat Terhadap Teknologi
c. Peningkatan norma dan etika internal ITS
d. Meningkatkan kerjasama antar warga dan internal ITS
e. Peningkatan Kualitas Hidup Masyarakat Sekitar

\section{RENCANA KEBERLANJUTAN PENELITIAN}

Hasil dari penelitian ini didapatkan analisa strategi aspek sosial ekonomi. Rumusan strategi ini kemudian digunakan untuk membantu pentahapan penyusunan roadmap CSR ITS, setelah dijabarkan menjadi program-program tertentu sesuai dengan potensi dan pengembangan masing-masing Kelurahan, yang kemudian akan disusun menjadi Roadmap CSR ITS di Draft Kebijakan.

\section{REFERENSI}

[1] W. R. Rahman, Nurdizal M., Efendi, A., Panduan Lengkap CSR. Jakarta: Penebar Swadaya, 2011.

[2] Bahrudin, Krisdyatmiko, D. A. Darmawan, and Soetomo, Buku Indikator Proper Hijau(Comdev).pdf. 2013.

[3] R. dan Sunarto, Pengantar Statistika. Bandung: CV Alfabeta, 2007.

[4] R. E. Walpole, Pengantar Statistika. Jakarta: PT Gramedia Pustaka Utama, 1993.

[5] T. Van Leeuwen and C. Jewitt, Handbook of visual analysis. SAGE, 2001.

[6] H. M. Alshuwaikat and I. Abubakar, "An integrated approach to achieving campus sustainability: 
assessment of the current campus environmental management practices," J. Clean. Prod., vol. 16, no. 16, pp. 1777-1785, Nov. 2008. 